Schrader, 2008). Leaf fall occurs in early

\title{
Eris Apple
}

\section{Thomas Sotiropoulos ${ }^{1}$}

Hellenic Agricultural Organization "Demeter," Department of Deciduous Tree Fruit Growing in Naoussa, Institute of Plant Breeding and Phytogenetic Resources, R.R. Station 38, 59035 Naoussa, Greece

\section{Nikolaos Koutinas}

Department of Agricultural Technology, School of Agricultural Technology, Food Technology and Nutrition, Alexander Technological Educational Institute of Thessaloniki, P.O. Box 141, 57400, Thessaloniki, Greece

Additional index words. cultivar description, fruit breeding, Malus $\times$ domestica

'Eris' is a midseason apple (Malus $\times$ domestica Borkh.) selection from a hybrid between the cultivars Red Chief and Black Ben Davis. Yield and fruit weight of 'Eris' are not significantly different from those of 'Red Chief', but are both higher than those of 'Black Ben Davis'. The fruit flesh of 'Eris' is white-yellowish, aromatic, crisp, and juicy. Fruit firmness of 'Eris' at harvest is high, higher than that of 'Red Chief' and similar to that of 'Black Ben Davis'. The total soluble solids content (TSS) of 'Eris' was higher than that of 'Black Ben Davis' and similar to that of 'Red Chief'. Total antioxidant power of 'Eris' is not significantly different from that of 'Black Ben Davis', but it is higher than that of 'Red Chief'. Suitable pollinizers of 'Eris' are the cultivars Golden Delicious, Gala, and Fuji. 'Eris' has the same degree of resistance with the cultivar Red Chief to the most serious apple pests and diseases. The fruit maintains firmness, juiciness, and flavor very well under standard cold storage $\left(0.5-1{ }^{\circ} \mathrm{C}\right)$ for $\approx 9$ months. In conclusion, 'Eris' seems to be a promising red apple cultivar due to its quality, which is distinctive and superior from 'Red Chief' as it has higher firmness, higher total antioxidant power, and lower preharvest fruit drop.

\section{Origin}

'Eris' (Greek mythology Goddess) originates from a cross between the apple cultivars Black Ben Davis and Red Chief. The breeding objectives were to improve the cultivar Red Chief (mainly to reduce its preharvest drop), which is the main red apple cultivar in Greece and other countries as well. The selection was propagated by grafting on the apple rootstock M.9. The selection was evaluated for five consecutive years (5-9 years of age of the trees) in Naoussa (northern Greece; long. $22^{\circ} 12^{\prime} 0^{\prime \prime} \mathrm{E}$, lat. $40^{\circ} 29^{\prime} 04^{\prime \prime} \mathrm{N}$, elevation $270 \mathrm{~m}$ ). The soil of the experimental orchard at a depth of 0 to $60 \mathrm{~cm}$ was a clay loam, slightly acidic ( $\mathrm{pH}$ 6.6), with low to medium electrical conductivity $\left(0.96 \mathrm{mS} \cdot \mathrm{cm}^{-1}\right)$ and low organic matter $(1.86 \%)$ content. Data from the

Received for publication 24 Feb. 2016. Accepted for publication 23 Mar. 2016.

${ }^{1}$ Corresponding author. E-mail: thosotir@otenet.gr. nearest meteorological station showed that the mean maximum temperature of the experimental area is $38^{\circ} \mathrm{C}$ in July and $9.5^{\circ} \mathrm{C}$ in January, whereas the mean minimum temperature in January is $-7{ }^{\circ} \mathrm{C}$.

The aim of this research was to give information about the new selection 'Eris' and to evaluate it in comparison with its parent cultivars regarding yield and some fruit quality attributes.

\section{Description}

Leaves and tree. 'Eris' grows well in fertile, acidic, well-drained sandy soils and loams, typical soils for apple cultivation (Barden and Neilsen, 2003). On M.9 rootstock, this cultivar is moderately vigorous and has a favorable and stable yield every year. Grafting was also performed on M.26 rootstock; however, since new plantations are planted at high-density super spindle system, data presented were on M.9 rootstock, which is more appropriate under such conditions (Ferree and Schupp, 2003; Kosina, 2010; Rom and Carlson, 1987; Sotiropoulos, 2008). First fruiting occurred at the 3 rd year of the trees. Full bloom of 'Eris' occurs between Apr. 18 and 23 (5 year's data). Unopened flowers of the selection 'Eris' are medium pink at full balloon stage, whereas at full bloom, the petals are mainly white with a slight medium pink blush. Suitable pollinizers of 'Eris' are the cultivars Golden Delicious, Gala, and Fuji. The leaves of 'Eris' have the following dimensions: length $8.0 \mathrm{~cm}$, width $5.9 \mathrm{~cm}$, length of leaf petiole $2.9 \mathrm{~cm}$, and thickness of leaf petiole $2 \mathrm{~mm}$. From our observations, 'Eris' has the same degree of resistance with the cultivar Red Chief to the most important pests and diseases such as codling moth (Cydia pomonella L.), apple leaf miners (Lyonetia clerkella L.), european red mite (Panonychus ulmi L.), apple scab (Venturia inaequalis Cooke Wint.), and powdery mildew [Podosphaera leucotricha (Ell. and Ev.) Salm.]. 'Eris' has a chilling hour requirement of 700-800, similar to 'Red Delicious' (Palmer et al., 2003). 'Eris' has similar resistance to sunburn with 'Red Delicious' and is more resistant than 'Gala' and 'Granny Smith'. The latest are very sensitive cultivars to sunburn (Fellicetti and
December.

Fruits. Fruit characteristics reported are mean values of 30 fruits from 35 trees ( 5 replications $\times 7$ trees) of each cultivar taken over 5 consecutive years. The experimental layout was a randomized complete block design including five replications of the three cultivars, including seven trees per replication. The differences between means were evaluated by using the Duncan's multiple range test at $P \leq 0.05$ carried out by SPSS version 17 (SPSS Inc., Chicago, IL).

Fruits of 'Eris' have a red skin color with the following dimensions: length $7.3 \mathrm{~cm}$, width $7.1 \mathrm{~cm}$, pedicel length $1.2 \mathrm{~cm}$, and pedicel thickness $1.5 \mathrm{~mm}$ (Fig. 1; Table 1). The width and depth of the calyx cavity of 'Eris' is 1.4 and $0.7 \mathrm{~cm}$, respectively. Fruits have an average number of small lenticels. For the climatic conditions of northern Greece, fruits mature at the second week of September (8-13). With regard to harvest maturity indices, the most commonly used are the TSS and flesh firmness. The use of this selection was tested primarily for fresh consumption since apple processing is not common in Greece, except juicing. Yield and fruit weight of 'Eris' are not significantly different from that of 'Red Chief', but they are higher than that of 'Black Ben Davis' (Table 1). Bearing happens mainly on spurs. Fruits of 'Eris' do not show symptoms of epidermal russeting. 'Eris' trees, like its parent 'Black Ben Davis', have a very low percentage of preharvest fruit drop $(<5 \%)$, expressed as a percentage of a total number of fruits per tree, whereas that of 'Red Chief' is significantly higher $(\approx 15 \%)$. The fruit flesh of 'Eris' is white-yellowish, aromatic, crisp, and juicy. Flesh of fruits does not brown soon after being cut. Fruit firmness $\left[\left(\mathrm{kg} \cdot \mathrm{cm}^{-2}\right)\right.$ measured with an Effegi penetrometer with 11-mm tip (Effegi model FT 327; Italy)] of 'Eris' at harvest is high, higher than that of 'Red Chief' and similar to that of 'Black Ben Davis' (Table 1). The TSS [(\%) measured with an Atago PR-1 electronic refractometer (Atago Co Ltd, Tokyo, Japan)] of 'Eris' were higher than those of 'Black Ben Davis' and similar to 'Red Chief' (Table 1). The $\mathrm{pH}$ of juice was not different among the three cultivars (Table 2). Total titratable acidity [(\%) measured as described by KoukourikouPetridou et al. (2007)] of the cultivar Black Ben Davis was higher than in the other two

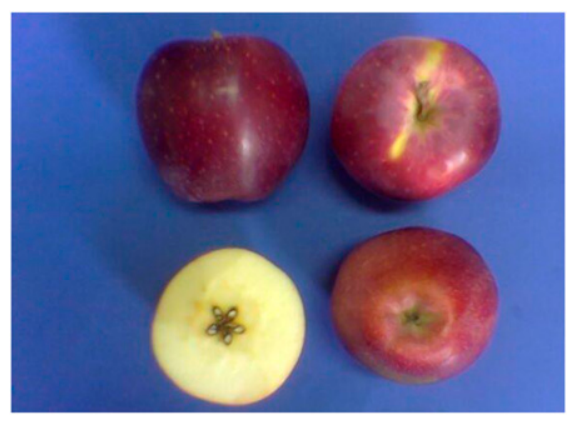

Fig. 1. Fruits of the apple cultivar Eris. 
Table 1. Yield, fruit weight, fruit firmness, and total soluble solids of the apple cultivars Eris, Red Chief, and Black Ben Davis when grafted on M.9 rootstock (average of 5 year's data, from the 5th until the 9th year of the trees).

\begin{tabular}{lcccc}
\hline Cultivar & $\begin{array}{c}\text { Yield } \\
(\mathrm{kg} / \text { tree })\end{array}$ & Fruit wt $(\mathrm{g})$ & $\begin{array}{c}\text { Fruit firmness } \\
\left(\mathrm{kg} \cdot \mathrm{cm}^{-2}\right)\end{array}$ & $\begin{array}{r}\text { Total soluble } \\
\text { solids }\left({ }^{\circ} \text { Brix }\right)\end{array}$ \\
\hline Eris & $54.74 \mathrm{a}^{\mathrm{z}}$ & $221.61 \mathrm{a}$ & $8.87 \mathrm{a}$ & $14.12 \mathrm{a}$ \\
Red Chief & $55.62 \mathrm{a}$ & $215.52 \mathrm{a}$ & $7.09 \mathrm{~b}$ & $13.45 \mathrm{a}$ \\
Black Ben Davis & $42.91 \mathrm{~b}$ & $179.13 \mathrm{~b}$ & $8.91 \mathrm{a}$ & $10.91 \mathrm{~b}$ \\
\hline
\end{tabular}

${ }^{\mathrm{z}}$ Means followed by the same letter in the same column are not significantly different (Duncan's multiple range test, $P \leq 0.05$ )

Table 2. Ascorbic acid content, total antioxidant power, total titratable acidity, and $\mathrm{pH}$ of juice of the apple cultivars Eris, Red Chief, and Black Ben Davis when grafted on M.9 rootstock (average of 2 year's data, from the 5 th until the 6 th year of the trees).

\begin{tabular}{lcccc}
\hline & $\begin{array}{c}\text { Ascorbic acid } \\
\text { (mg/100 g } \\
\text { fresh wt) }\end{array}$ & $\begin{array}{c}\text { Total antioxidant } \\
\text { power (mmol ascorbic } \\
\text { acid equivalent/g fresh wt) }\end{array}$ & $\begin{array}{c}\text { Total titratable } \\
\text { acidity (\%) }\end{array}$ & pH of juice \\
\hline Eris & $7.80 \mathrm{ab}^{z}$ & $13.17 \mathrm{a}$ & $3.01 \mathrm{~b}$ & $3.9 \mathrm{a}$ \\
Red Chief & $7.11 \mathrm{~b}$ & $9.99 \mathrm{~b}$ & $2.91 \mathrm{~b}$ & $3.5 \mathrm{a}$ \\
Black Ben Davis & $8.43 \mathrm{a}$ & $12.91 \mathrm{a}$ & $3.45 \mathrm{a}$ & $3.7 \mathrm{a}$ \\
\hline
\end{tabular}

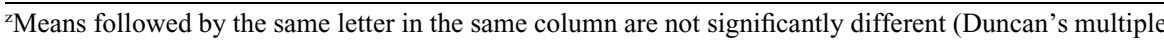
range test, $P \leq 0.05$ ).

Table 3. Color parameters $(L, a$, and $b)$ of the apple cultivars Eris, Red Chief, and Black Ben Davis when grafted on M.9 rootstock (average of 5 year's data, from the 5th until the 9th year of the trees)

\begin{tabular}{lccc}
\hline Cultivar & $L$ & $a$ & $b$ \\
\hline Eris & $42.62 \mathrm{a}^{\mathrm{z}}$ & $20.44 \mathrm{a}$ & $22.75 \mathrm{a}$ \\
Red Chief & $41.75 \mathrm{a}$ & $19.55 \mathrm{a}$ & $23.52 \mathrm{a}$ \\
Black Ben Davis & $32.19 \mathrm{~b}$ & $17.98 \mathrm{a}$ & $22.13 \mathrm{a}$ \\
\hline zMeans followed by the same letter in the same \\
column are not significantly different (Duncan's \\
multiple range test, $P \leq 0.05$ ).
\end{tabular}

cultivars (Table 2). Total antioxidant power (Benzie and Strain, 1996) of 'Eris' is not significantly different from that of 'Black Ben Davis', but it is higher than that of 'Red Chief'. Ascorbic acid content measured by oxalic acid 1\% (Haddad, 1977) of 'Eris' was not different from the other two cultivars (Table 2). Regarding fruit color measurements (McGuire, 1992), L parameter (lightness) of the cultivars Eris and Red Chief was

\section{Literature Cited}

Barden, J. and G. Neilsen. 2003. Selecting the orchard site, site preparation and orchard planning and establishment. In: D. Ferree and I. Warrington (eds.). Apples: Botany, production and uses. CAB International, Wallingford, UK.

Benzie, I.F. and J. Strain. 1996. The ferric reducing ability of plasma (FRAP) as a measure of 'antioxidant power': The FRAP assay. Anal. Biochem. 44:276-287.

Fellicetti, D.A. and L.E. Schrader. 2008. Photooxidative sunburn of apples: Characterization of a third type of apple sunburn. Intl. J. Fruit Sci. $8: 160-172$.

Ferree, D. and J. Schupp. 2003. Pruning and training physiology. In: D. Ferree and I. Warrington (eds.). Apples: Botany, production and uses. CAB International, Wallingford, UK.

Haddad, P. 1977. Vitamin C content of commercial orange juices. An analytical project. J. Chem. Educ. 54:192

Kosina, J. 2010. Effect of dwarfing and semi dwarfing apple rootstocks on growth and productivity of selected apple cultivars. Hort. Sci. 37:121-126.

higher than that of Black Ben Davis (Table 3). The parameters $a$ and $b$ were not different for the three cultivars. The fruit maintains firmness, juiciness, and flavor very well under standard cold storage $\left(0.5-1{ }^{\circ} \mathrm{C}\right)$ for $\approx 9$ months. During storage, fruits did not show the postharvest physiological disorders (Watkins, 2003) "external browning" or "water core," but some years, fruits showed "bitter pit." However, this problem was resolved by calcium sprays.

In conclusion, Eris seems to be a promising apple cultivar due to its quality attributes.

\section{Availability}

'Eris' apple is presently available from the Institute of Plant Breeding and Phytogenetic Resources, Department of Deciduous Tree Fruit Growing in Naoussa. 'Eris' apple will be in the near future registered in the official list of the Greek Ministry of Agriculture.
Koukourikou-Petridou, M., D. Voyatzis, D. Stylianidis, T. Sotiropoulos, and I. Therios. 2007. Effects of some growth regulators on pre and after storage quality of Red Chief Delicious apples. Eur. J. Hort. Sci. 72:8-11.

McGuire, R. 1992. Reporting of objective color measurements. HortScience 27:1254-1255.

Palmer, J., J. Prive, and D. Tustin. 2003. Apple physiology and environmental influences: Temperature. In: D. Ferree and I. Warrington (eds.). Apples: Botany, production and uses. CAB International, Wallingford, UK

Rom, R. and R. Carlson. 1987. Rootstocks for fruit crops. John Wiley \& Sons, New York, NY.

Sotiropoulos, T. 2008. Performance of the apple (Malus domestica Borkh) cultivar Imperial Double Red Delicious grafted on five rootstocks. Hort. Sci. (Prague) 35:7-11.

Watkins, C. 2003. Principles and practices of postharvest handling and stress. In: D. Ferree and I. Warrington (eds.). Apples: Botany, production and uses. CAB International, Wallingford, UK. 